\title{
BANKS: DETERIORATION OF ASSETS QUALITY AND EARNINGS REDUCTION ${ }^{1}$
}

\author{
M.Khromov
}

In 2015, deterioration of bank assets quality and reduction of profitability obtained from net operating income have led to a drastic fall of bank earnings. This deprived the banking sector of the main source of capital base replenishment while capital adequacy level was close to a critical point. Up to the end of summer 2015, bank capital growth was mainly true of major banks. As a result, while the banking sector was increasing capital base the significant number of banks still operated with insufficient bank stock to sustain further deterioration of assets quality without the additional support.

Overall, the state of the Russian banking sector in the course of the whole period from end-2014 can be characterized as rather unstable. This outcome is explained by several negative trends surfaced in the course of this ear.

1. Noticeable deterioration of bank assets quality resulting from economic stagnation, actual fall of economic agents' income and lower ability of borrowers to timey service their bank obligations.

Reduction of the assets quality is reflected in banker's books in the form of reserves transferred for loan loss provisions and other types of assets. In each case, the amount of reserves is ultimately determined by a compromise reached between a bank and the regulator. Nevertheless, judging by a relative volume of accumulated reserves and their dynamic one can estimate risks assumed by the banking sector as a whole.

Assessing current state of the banking sector, one should note that prior to the period of enhanced growth of risks commenced from H2 1014, the quality of bank assets was noticeably worse than, for instance, prior to 2008-2009 crisis. For example, the intercrisis minimum ratio of the reserves for all types of assets loss provision to the total banking sector assets which was reached at the turn of 2014 constituted 5\%. Ratio of reserves for potential credit portfolio loss provision to the volume of the banking sector credit portfolio constituted $6.8 \%$ for the same date which is the low bottom from $\mathrm{H} 1$ 2009. Meanwhile, in 2008 these ratios constituted $2.9 \%$ and $3.9 \%$, respectively. This signifies that prior to the present period of instability the quality of bank assets was 1.7-1.8-fold inferior than prior to the previous crisis.

Over the last year compared to 2008-2010, dynamic of provision for reserves turned out to be not so rapid. From September 2014 to August 2015, the volume of reserves allocated for potential losses went up by $45 \%$,

1 The article was published in Monitoring of Russia's Economic Outlook. Trends and Challenges of Socio-economic Development. 2015, No. 13, October.

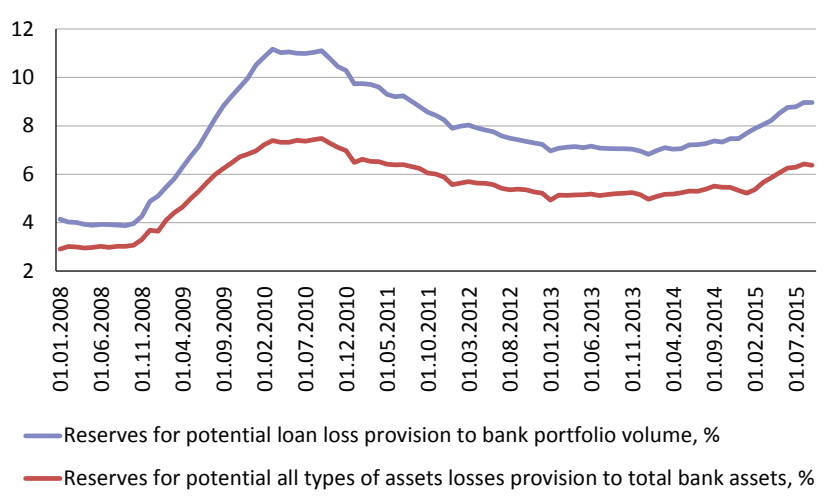

Fig. 1. Indicators of bank assets quality, $\%$

in the meantime maximum growth rate of this indicator in 2009 reached $143 \%$. Increase of ratio between reserves and aggregate assets looks rather moderate. Nevertheless, in absolute terms deterioration of banks assets is more costly for the banks. Solely for eight months from the turn of the year, aggregate allocation to reserves for potential losses constituted over Rb 900.o bn and for September 2014 - August 2015 growth of reserves exceeded Rb 1.5 trillion.

2. Wide scale losses accumulated by majority of banks which reduce cumulative financial result of the banking sector close to zero. Rather moderate financial outcome posted this year is determined both by significant allocation to reserves and by reduction of earnings obtained from net operating income.

As a whole, the banking system has been teetering on the edge of profitability from end-2014. For first eight months of the current year cumulative financial result of the banking sector constituted $\mathrm{Rb} 76.0 \mathrm{bn}$ before tax. This is eightfold less than for the corresponding period of the last year (Rb 596bn). Taking into consideration tax deductions the cumulative financial result for this period is negative ( $\mathrm{Rb}-11.0 \mathrm{bn})$.

In 2015, according to the latest data, $30 \%$ of functional credit organizations are loss making: 232 out of 774 as of the period-end for eight months of 2015. 


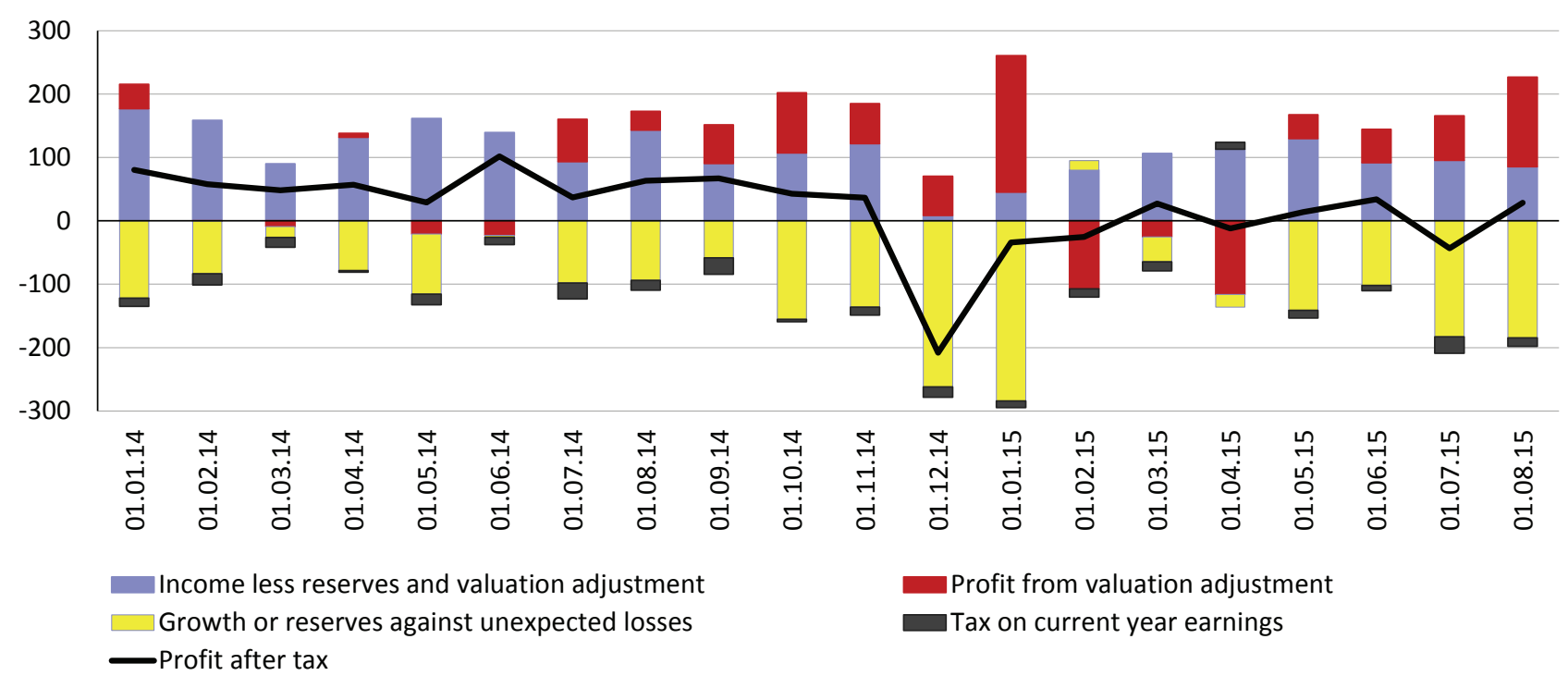

Fig. 2. The main components of the banking sector financial results, Rb billion

As was noted earlier, the deterioration of assets quality has become the main factor of such earnings reduction. Moreover, the banking sector began getting less net operating income. During first eight months of 2015, the banking sector earnings less operations with reserves and accounts valuation adjustment have fallen by more than $30 \%$ compared to the same period of 2014 ( $R b$ 747bn against $\mathrm{Rb}$ 1,094bn).

This was the result of the outstripping growth of interest costs of the banks. Significant hike of the key interest rate by the Bank of Russia at end-2014 affected on the cost of borrowed assets faster than on the assets cost. Firstly, short-term assets borrowed from the Bank of Russia whose cost is tied to the key interest rate formed noticeable part of banking liabilities (over $10 \%$ in certain months of the current year). Secondly, at end-2014 many banks had trouble with liquidity and were forced to raise interest rates on deposits following the key rate. Banks' customers have taken advantage of this by rolling over old deposits or depositing at the increased rate. As a result, in $\mathrm{H} 12015^{1}$, amid a relatively stable resource base the interest costs of banks went up by $91 \%$ compared to $\mathrm{H} 12014$.

In the meantime, the banks could not freely raise the charge on already invested funds. In other words, actual maturity of the credit portfolio was higher than maturity of borrowed assets. New loans in 2015 were granted at increased interest rates while major share of the credit portfolio was serviced at the previously set interest rates. Interest income of the banks in $\mathrm{H} 1$ 2015 have turned out to be by barely $29 \%$ above its year-earlier level. As of end-H1 2015, net interest income fell by $36 \%$ from $\mathrm{Rb} 1,090.0 \mathrm{bn}$ in 2014 to $\mathrm{Rb}$ 700.0 bn in 2015.

1 Detailed data on the composition of the bank income and expenses is available solely on the quarterly basis.
3. Rather low indicators of capital adequacy which is a direct result of both lack of earnings and an indirect one - reduced profitability of the bank capital which decreases incentives for the owners and other investors for investing additional funds in the banking business.

Despite the magnitude of the assets quality indices and banking profit, the direct effect on the sustainability of the banking sector is exercised by the level of capital adequacy which ensures feasibility of the banks to absorb incurred losses. Similar to the situation with the credits quality in 2014 the banking sector registered capital adequacy indicator inferior to the one registered in 2008. Then $\mathrm{H} 1$ value did not drop below 14.5\% (1 October 2008), and with the support for the banking sector via mechanism of subordinated loans at the expense of the Bank of Russia and NWF assets its level exceeded 20.0\% already in H2 2009.

As of the period-end for November 2015, the banking sector capital adequacy fell below $12 \%$. Over the past months of 2015, mainly thanks to the state support the banking sector capital adequacy went up to $13.2 \% .^{2}$ Meanwhile, the growth of the capital base was mainly at the expense of the major state banks. Over December 2014 - July 2015, the bank stock of the major state banks has increased by Rb $570 \mathrm{bn}$, and of all other banks - barely by Rb $22 \mathrm{bn}$. In August 2015, bank stock of the major state banks went up by $\mathrm{Rb}$ $181 \mathrm{bn}$. As a result, capital adequacy of the major state banks has increased by nearly 2 p.p. from $11.1 \%$ as of 1 December 2014 to $13.0 \%$ as of 1 September 2015. Capital adequacy of other banks has gone up barely by 0.3 p.p. from 13.1 to $13.4 \%$.

2 IEP estimates, the official data regarding the banking sector as a whole has not been released as of the date of the monitoring publication. 
At the same time, there are significant number of banks whose capital adequacy ratio is below average and is close to $10 \%$ threshold or even below it. As of 1 September 2015, fourteen banks failed to comply with the capital adequacy ratio (these banks are in the process of financial sanation and are under the DIA (Deposits Insurance Agency) management), fifty-two banks have the capital adequacy ratio in the range of 10 to $11 \%$, and $68 \%$ - in the rage of 11 to $12 \%$. Thus, over $15 \%$ of the total number of banks whose total banking assets amount to about $20 \%$ have capital adequacy ratio close to the threshold and do not comply with it.

Furthermore, from the turn of 2015, sixty-one credit organizations have lost their licenses. Tell the truth, mainly small credit organizations are being removed from the market. And larger problem banks are subject to sanation. For instance, if average volume of bank assets on the date of license revocation in 2015 constituted $\mathrm{Rb} 12 \mathrm{bn}$, than for the banks who were subjected to financial sanation this year average assets amount came to $\mathrm{Rb} 38 \mathrm{bn}$.

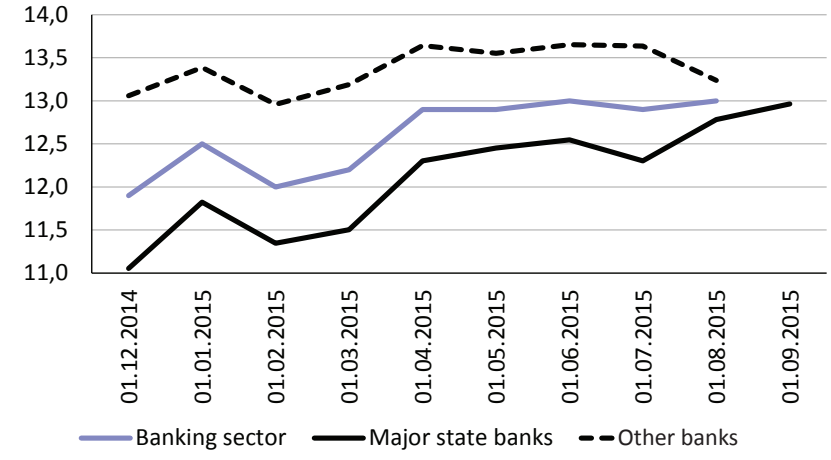

Fig. 3. Capital adequacy ratio in the banking sector, state and other banks, \% 